\title{
MEASUREMENT OF DEFLECTION LINE ON BRIDGES
}

\author{
Rudolf Urban, Martin Štroner \\ Department of Special Geodesy \\ Czech Technical University in Prague \\ Faculty of Civil Engineering \\ Prague, Czech Republic
}

\begin{abstract}
Prestressed concrete bridges are very sensitive to the increase in long-term deflections. Reliable forecasts of deflections of bridge structures during construction and durability are crucial for achieving good durability. The main results of measurements are the changes of the deflection line of the bridge structures, which places special demands on the measurement procedure. Results from measurements are very useful for the improvement of mathematical prediction methods of behaviour of long span prestressed concrete structures.
\end{abstract}

Keywords: bridge, deflection, time sample method, trigonometry

\section{Introduction}

In the last five years, the deflection line was measured on three bridges (Štroner et al., 2012; Vráblík et al., 2009). Long-term deformations are measured at fixed points on the structure (above supporting for analysis of their long-term settlement and in the intermediate points of the end span and middle span for observing long-term deformations of the prestrained concrete structure caused both by rheological signs of concrete - creeping and shrinkage, and by other possible effects, e.g. decreases in prestress etc.). This measurement is performed for experts in the dynamics of bridge structures from Faculty of Civil Engineering in Prague (Křístek \& Vráblík, 2007; Vodsloň).

The results of such measuring are time development of the real shape of the structure - comprising both the starting shape and the deflection line - in the analysed points. So as to find out an exact shape of the deflection line, a detailed focusing of the deformed shape of the supporting structure in large amount of points was designed. Possible found "anomalies“ in the course of the deflection line might 
point to failures of the structure causing enormous long-term increase in deflections of this bridge structure.

\section{Measured bridges}

The first measured bridge was a newly built bridge over the river Labe. It was put into operation in December 2009. Contractor of the structure was SMP CZ, part of VINCI Group. Designer was PONTEX Ltd. The length of the main span is record for this type of structure in Czech Republic. For this reason the measurements of deformations of the bridge over the river Labe at Litoměřice has begun immediately after the putting bridge into operation.

The second bridge was long span prestressed concrete bridge across the river Labe in Mělník. As well as other concrete bridges with large spans, this bridge is also characterized by permanent increase in deformations in time. Therefore the structure has been permanently observed since its putting into operation in September 1994. The evaluation of monitoring results clearly shows that even after almost 15 years since putting the bridge into operation there is no stabilization of increase in deformations.

The third bridge was concrete bridge with an inner joint in the middle of the main field across the river Želivka at Brzotice. The structure was measured only twice in 2009 for research of deflection line, at night and on sunny day.

\subsection{Bridge structure description}

The bridge over the river Labe near Litomerice is part of the road II/247 - it is a connection between the industry area Prosmyky and D8 highway. The superstructure is designed as a continuous beam with box girder cross-section. Total length of the structure is $584.5 \mathrm{~m}$. It is divided to 7 spans with lengths $43+64+72+90+151+$ $102+60 \mathrm{~m}$.

The width of the bottom deck is $7.5 \mathrm{~m}$; the width of the upper deck is 14.5. The main structure span (length $151 \mathrm{~m}$ ) and neighbor spans (length 90 and $102 \mathrm{~m}$ ) were constructed by balanced cantilevers method. These spans are made by two cantilevers with tapered cross section height (varies from $3.5 \mathrm{~m}$ in the middle of the span to $7.5 \mathrm{~m}$ above supports) and changing thick of the bottom slab (varies from $270 \mathrm{~mm}$ to $1200 \mathrm{~mm}$ ) - see Fig. 1.

The left cantilever beam is symmetrical with the length of $150 \mathrm{~m}$. The right cantilever beam length is $160 \mathrm{~m}$. Approaching spans are designed as continuous beam with constant cross section height $3.5 \mathrm{~m}$ and the thick of the bottom slab 270 $\mathrm{mm}$.

Long span prestressed concrete bridge across the river Labe in Mělník (Fig. 2) is the main part of the bridging transferring the $1 / 16$ communication. It was designed as a through girder with span length $72.05+146.2+72.05 \mathrm{~m}$. With the main span length $146.2 \mathrm{~m}$ it is still one of the biggest overhung concrete bridge in operation in Czech Republic.

The bridge over the river Želivka near Brzotice (Fig. 3) is the part of the road II/150 - connection between the valley of Sázava and D1 highway. The construction of bridge is designed as a concrete frame structure with four fields with inner joints in the 2nd and 3rd field. Length of bridge is $306 \mathrm{~m}$, width $13 \mathrm{~m}$ and pillar are $65 \mathrm{~m}$ high. 


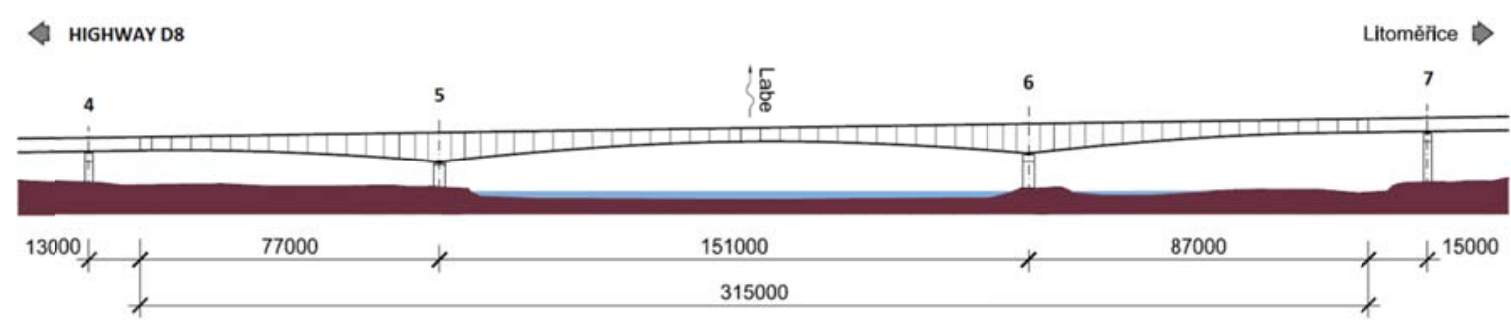

Fig. 1a. Longitudinal section of superstructure

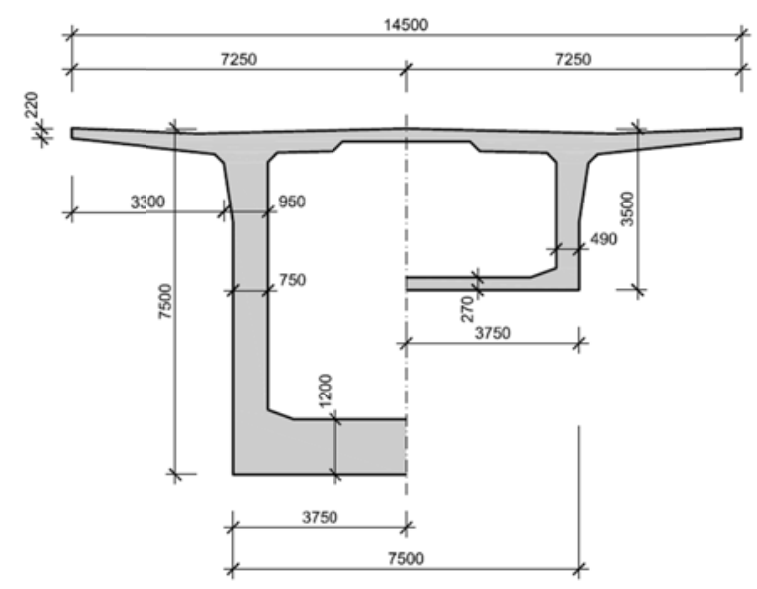

Fig. 1b. Cross section of superstructure

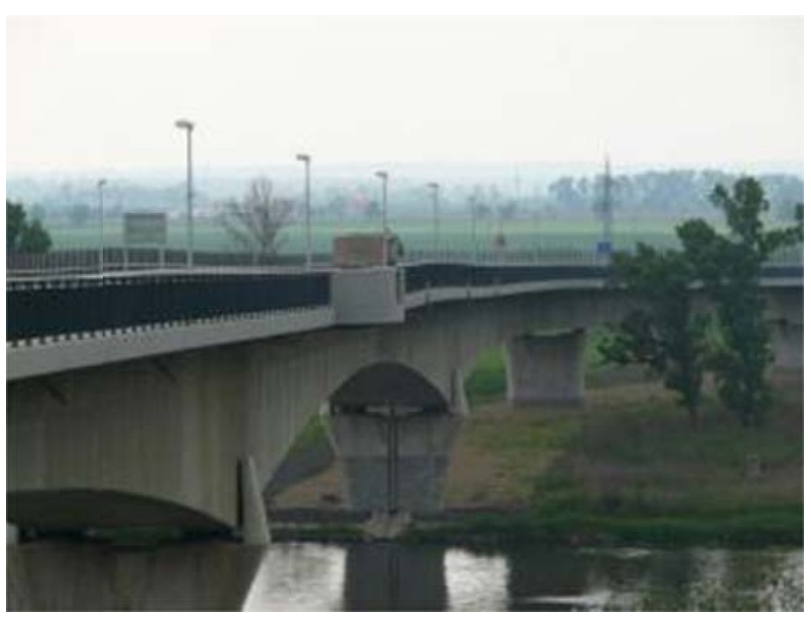

Fig. 2c. The bridge near Litoměřice

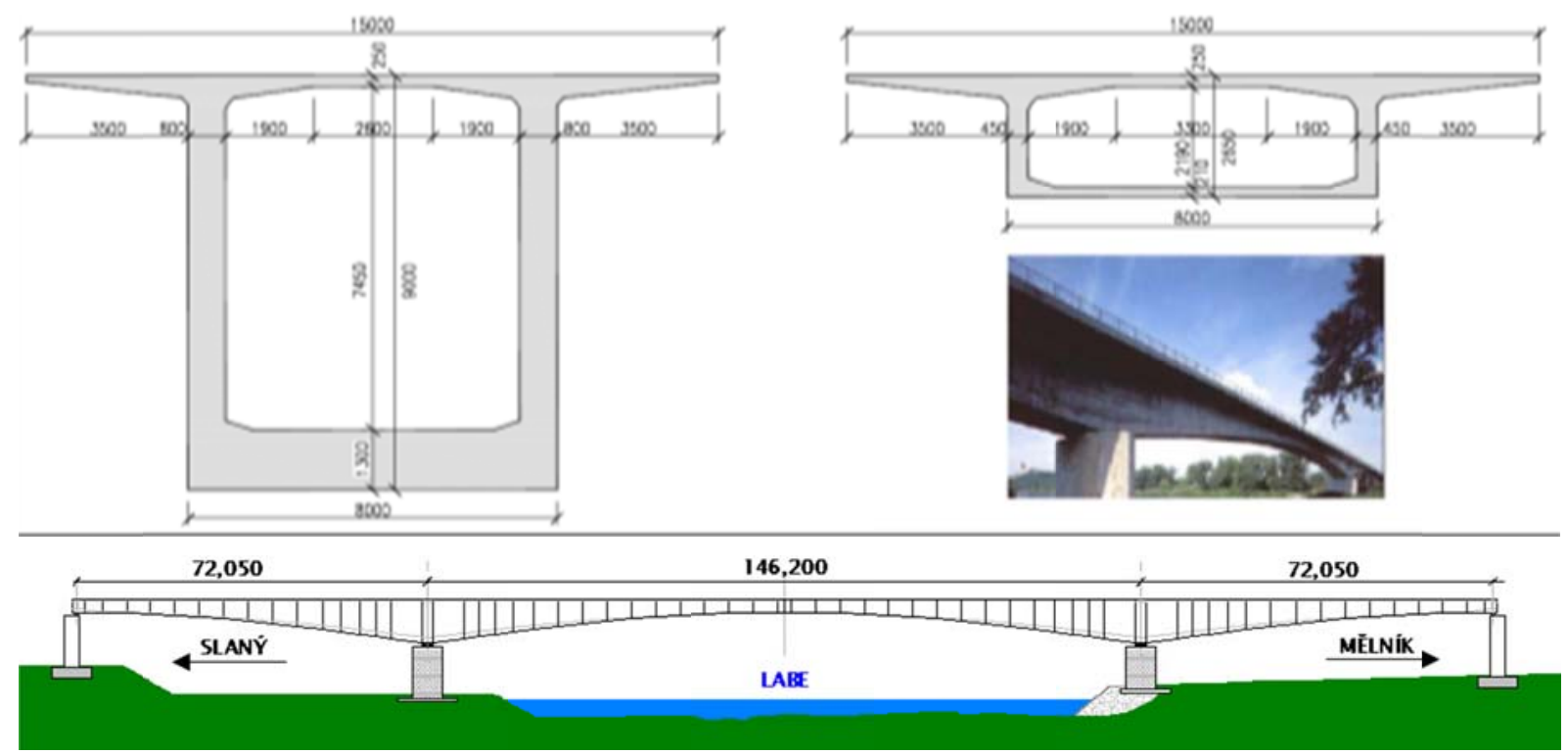

Fig. 2. The bridge near Mělník 


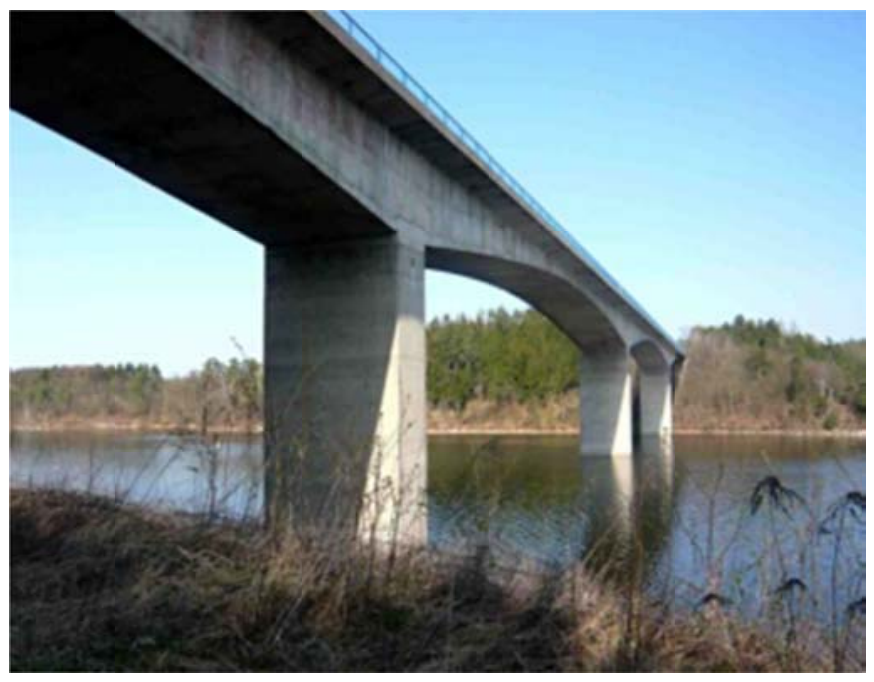

Fig. 3. The Bridge near Brzotice

\section{Geodetic measurements}

Geodetic measurements are performed in order to monitor deflection changes of observed points arranged in two longitudinal profiles on both sides of the bridge structure (Brzotice has only one profile). Monitored points are stabilized with taped metal nail markers or by driving plugs fitted into the hole in the structure. Stabilization was implemented either by contractor after completing the construction (bridge near Litoměřice) or by geodetic team equipped with special professional drilling kit with stabilization done before the very measurement.

Due to the large distances and required speed and precision (standard deviation of height determination is $2 \mathrm{~mm}$ ) trigonometric technology of heights determination was used.

Robotic total station Trimble S6 HP was used for the measurement. This machine uses automatic targeting to Trimble prism. Measurements are realized from one or two standpoints connected to the point of basic surveying networks used for the construction of the bridge or other stable points near bridge. Point of height control has been verified by measurements on a minimum of two more stable points.

Each point was measured in two positions, each position having dual targeting and subtraction. After changing of standpoint, control measurements of available points were realized. Measurements of the connection points were performed repeatedly prior the beginning and end of the measurements.

In parallel with the geometry measurements, air and structure temperatures were analyzed. The temperature measurements were made by a calibrated digital thermometer GREISINGER, the temperature structure was measured by contactless thermometer Ahlborn Messtechnik Amir 7811.

\subsection{Measurement instruments and technology}

The Trimble S6 Robotic instrument $\left(\sigma_{\varphi}=0.3 \mathrm{mgon}, \sigma_{\mathrm{D}}=1 \mathrm{~mm}+1 \mathrm{ppm} \mathrm{D)}\right.$ with a relevant omnidirectional reflection prism was used for the measuring (Fig. 4). It is a total station with automatic observation of an aim and spacing, which also enables automatic targeting on an omnidirectional reflection prism.

The bridge structure was measured by the space polar method. The measuring technology was determined in dependence on time change of the bridge structure 
shape and on accuracy requirements. The exact leveling technology, which would determine height of points with higher accuracy, could not be used for reason of extremely higher measuring time, which would cause a significantly bigger movement of the structure owing to temperature change and thereby a significantly higher measuring inaccuracies (the measuring would not be continual and a correction by means of a time sample would be infeasible).
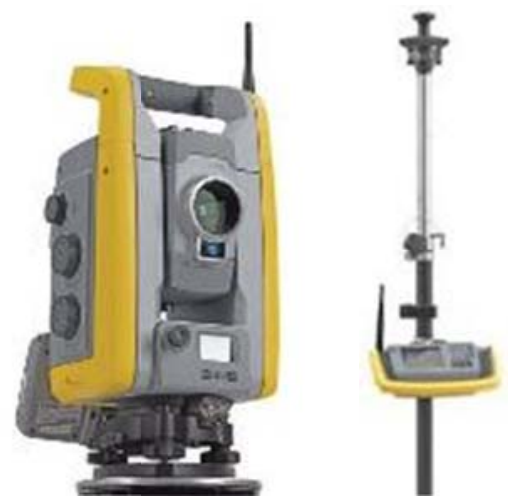

Fig. 4. Trimble S6 Robotic, a range pole with an omnidirectional prism

\subsection{Measuring configuration}

The measuring configuration is shown in Fig. 5 for bridge near Litoměřice and in Fig. 6 for bridge near Mělník. Configuration of measuring on bridge near Brzotice was very simple. 88 points with exactly the same spacing were situated on the right side of the bridge. The bridge structure shape was changing in the course of measuring. When designing the configuration measuring the assumption was that the bridge temperature is stable (measuring was realized at night). In case of temperature instability, the „time sample method“ was used for correction.

\subsection{Time sample method}

Determination of heights of such a large number of points cannot be at present carried out from the technological point of view with standard deviation c. $1 \mathrm{~mm}-2$ $\mathrm{mm}$ in such a short time, so that the shape of the structure does not change owing to temperature changes in time during measuring the first and the last point. To minimize these undesirable changes must be the measurement realized at night (22:30 hrs. $-4: 00$ hrs.). That is why approximately $1 / 5$ points (each fifth point) were refocused for check reasons in a significantly shorter time (c. $45 \mathrm{~min}$ ) after finishing the first measurements. Changes between height determination of the first and the last point can be taken here for significantly smaller and the sample of points determined in this way can be used to determine a correction curve, by means of which it is possible to bring the measured points into the correct position and to suppress systematic errors. Detailed description can be found in article (Vráblík et al., 2009). 


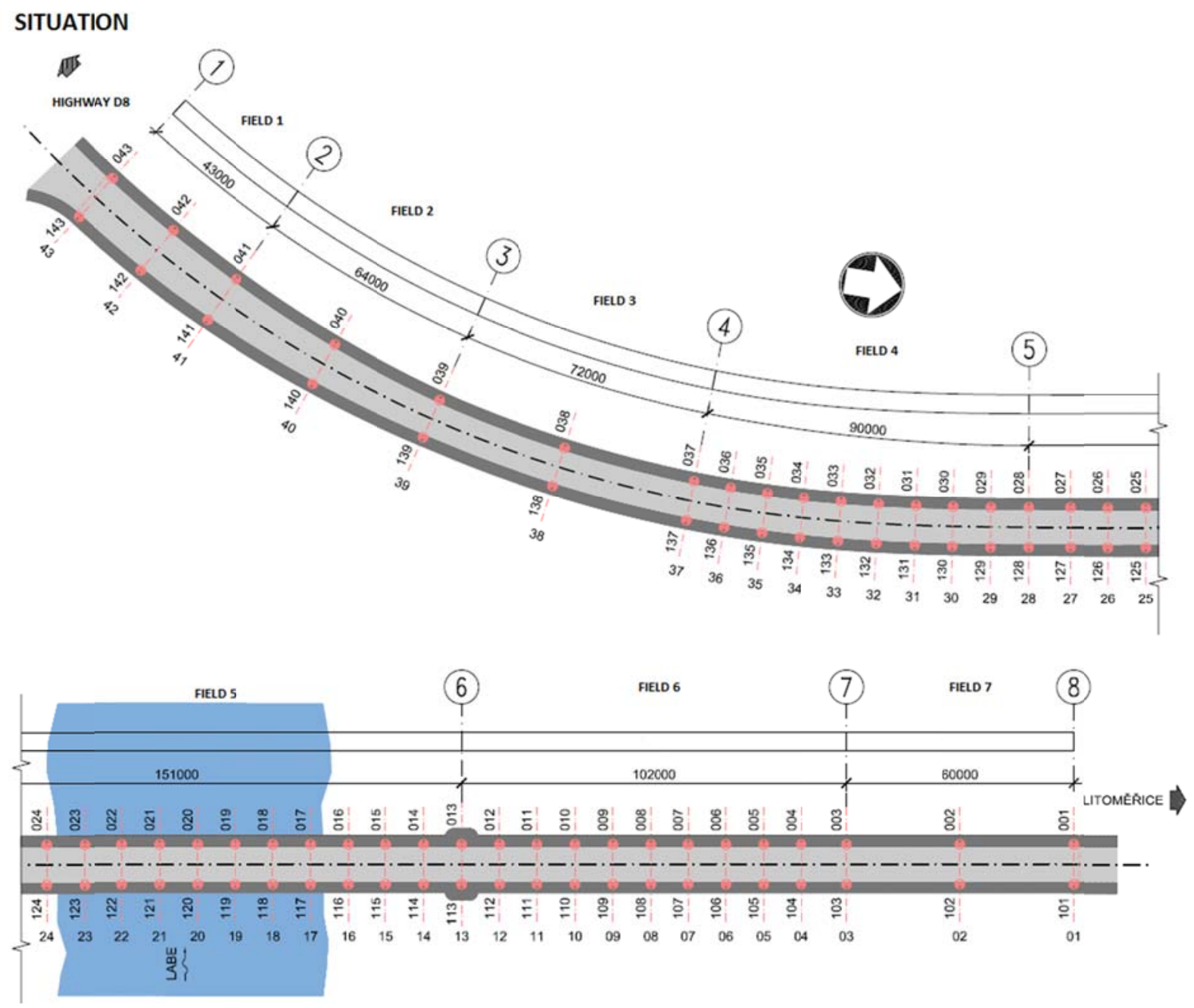

Fig. 5. Monitored points (Litoměřice)

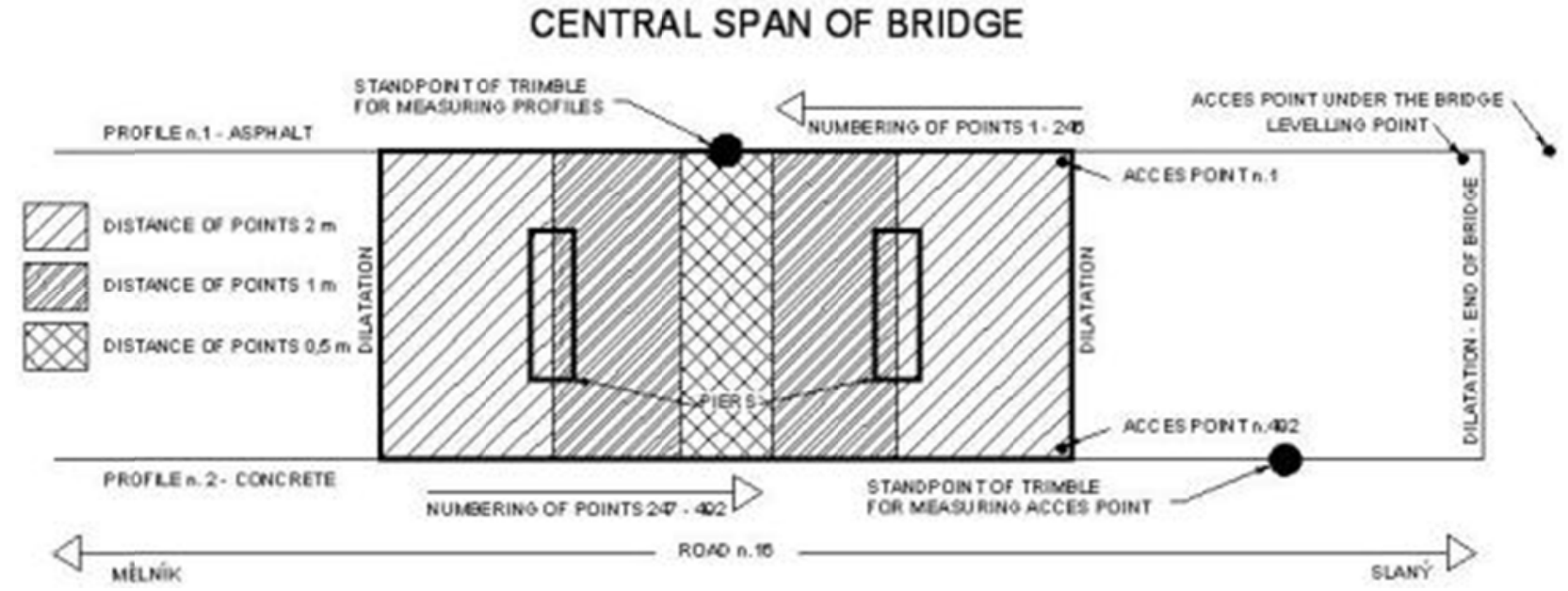

Fig. 6. Monitored points (Mělník) 


\section{Analysis of height measuring accuracy}

With respect to the way of signalization of points for measuring (a range pole with a prism held by a lineman) it is possible to estimate standard deviation of point height determination (in the local system). All bridge structures were measured in local height system, which is determined by stable points of surveying network (setting out network). The manufacturer states the standard deviation of the zenith angle measured in two positions amounting to 0.3 mgon. According to the standard deviation accumulation law the standard deviation of the $2 \times$ targeted zenith angle in one position is 0.3 mgon again. For maximum distance of the point from the standpoint of $300 \mathrm{~m}$ (two standpoints on bridge), the standard deviation of the determined height therefore equals $1.4 \mathrm{~mm}$. Standard deviation of connection to reference point is $0.5 \mathrm{~mm}$, refraction effect on the estimated value of the connection is $1.0 \mathrm{~mm}$ (This value is an estimate of the maximum effect on the connection. Although the measurement is made at night in relatively stable atmospheric conditions, the effect of refraction is negligible, since structure in temperature changes more slowly than the atmosphere, also microclimate is not homogenous.).

Influence of inaccurate settlement of the spherical level on the target device (range pole no verticality) on the determined height is insignificant for level sensitivity $4^{\prime}-6^{\prime}$ and prism height $1.5 \mathrm{~m}$. Standard deviation of height can be therefore estimated with value of $1.8 \mathrm{~mm}$.

The standard deviation calculated from the repeated aiming when measuring height attachment was $0.67 \mathrm{~mm}$ for maximum distance of $50 \mathrm{~m}$ (this value was reached during testing of the survey method), which corresponds to the accomplished accuracy analysis (Štroner \& Hampacher, 2011). Each point was measured only once (except for a few control points), because the structure is not absolutely stable and repeatable measurement would be meaningless.

Effect of refraction was included in the apriori analysis of the accuracy; the correction factor for bridge construction could not be reliably determined, because of the unstable atmospheric conditions. The estimate of the maximum influence of refraction was determined by experimental measurements.

\subsection{Measurement of stages on bridge near Litoměřice}

Measurements on bridge near Litoměřice were carried out in dates specified in the Table 1. Average temperatures are also specified for each stage. Measurements were always successful with results controls confirming the desired accuracy.

Six measurements were determined by the relative heights of all monitored points from the reference geodetic connection point. Displacements (structure deformation) of each point relative to the base 0th stage are shown on Fig. 7 and Fig. 8. These pictures show significant decrease in the main field, which is situated above river.

Table 1. Measurement stages

\begin{tabular}{|c|c|c|c|}
\hline \multicolumn{4}{|c|}{ Measurement stages } \\
\hline Stage & Date and time & $\begin{array}{c}\text { Average atmosphere } \\
\text { temperature }\left({ }^{\circ} \mathbf{C}\right)\end{array}$ & $\begin{array}{c}\text { Average structure } \\
\text { temperature }\left({ }^{\circ} \mathbf{C}\right)\end{array}$ \\
\hline $\mathbf{0 .}$ & $29.9 .2010(21: 00-4: 00,30.9 .2010)$ & 9,0 & 8,2 \\
\hline $\mathbf{1 .}$ & $13.5 .2011(21: 30-2: 00,14.5 .2011)$ & 11,0 & 13,0 \\
\hline $\mathbf{2}$ & $27.9 .2011(23: 00-2: 00,28.9 .2011)$ & 15,4 & 14,9 \\
\hline $\mathbf{3 .}$ & $4.11 .2011(22: 30-1: 30,5.11 .2011)$ & 8,5 & 6,9 \\
\hline $\mathbf{4 .}$ & $12.4 .2012(23: 00-2: 00,13.4 .2012)$ & 6,7 & 4,9 \\
\hline $\mathbf{5 .}$ & $30.5 .2012(23: 30-2: 00,31.5 .2012)$ & 12,0 & 15,2 \\
\hline
\end{tabular}




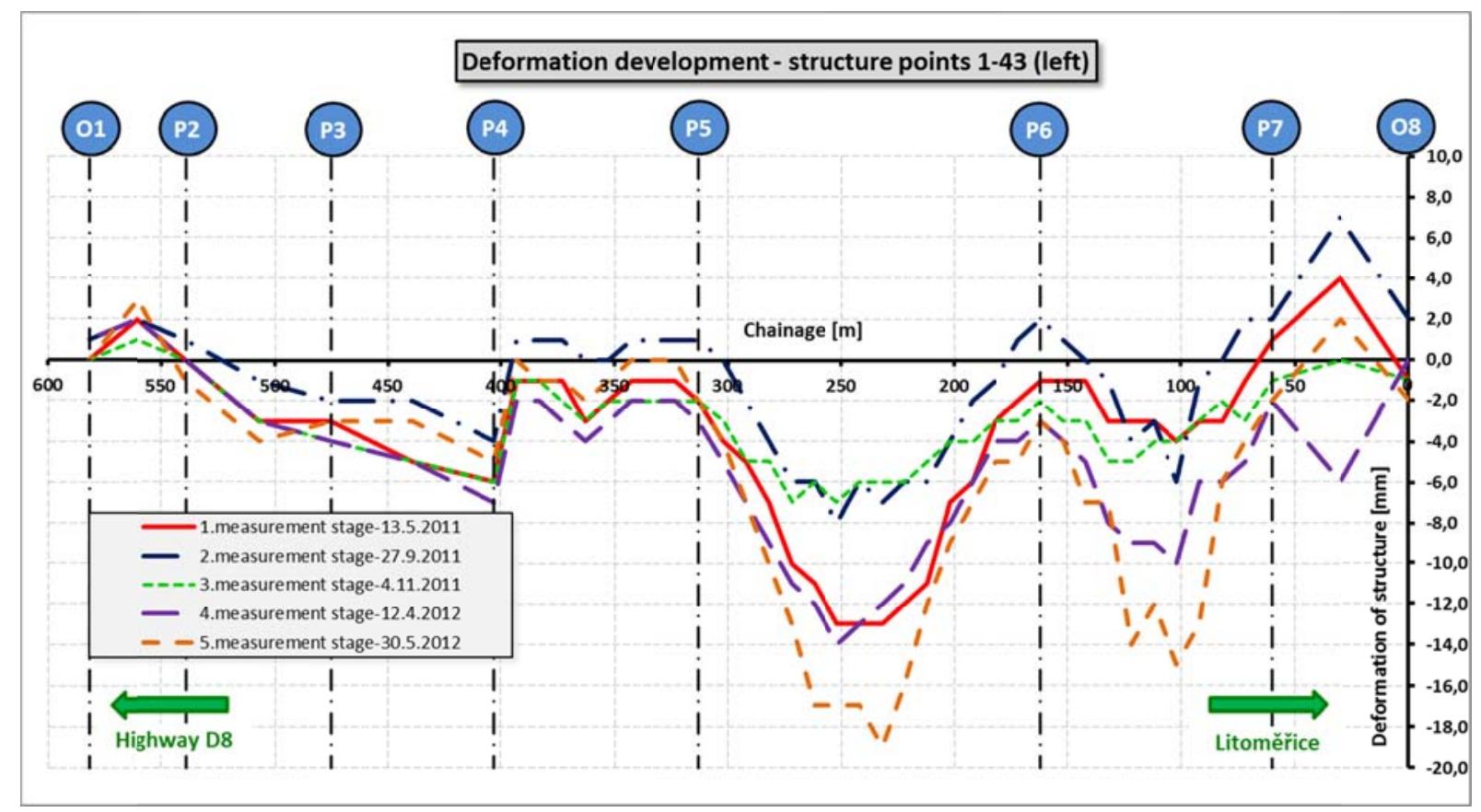

Fig. 7. Development of structure deformation compared $0^{\text {th }}$ measurement stage (left)

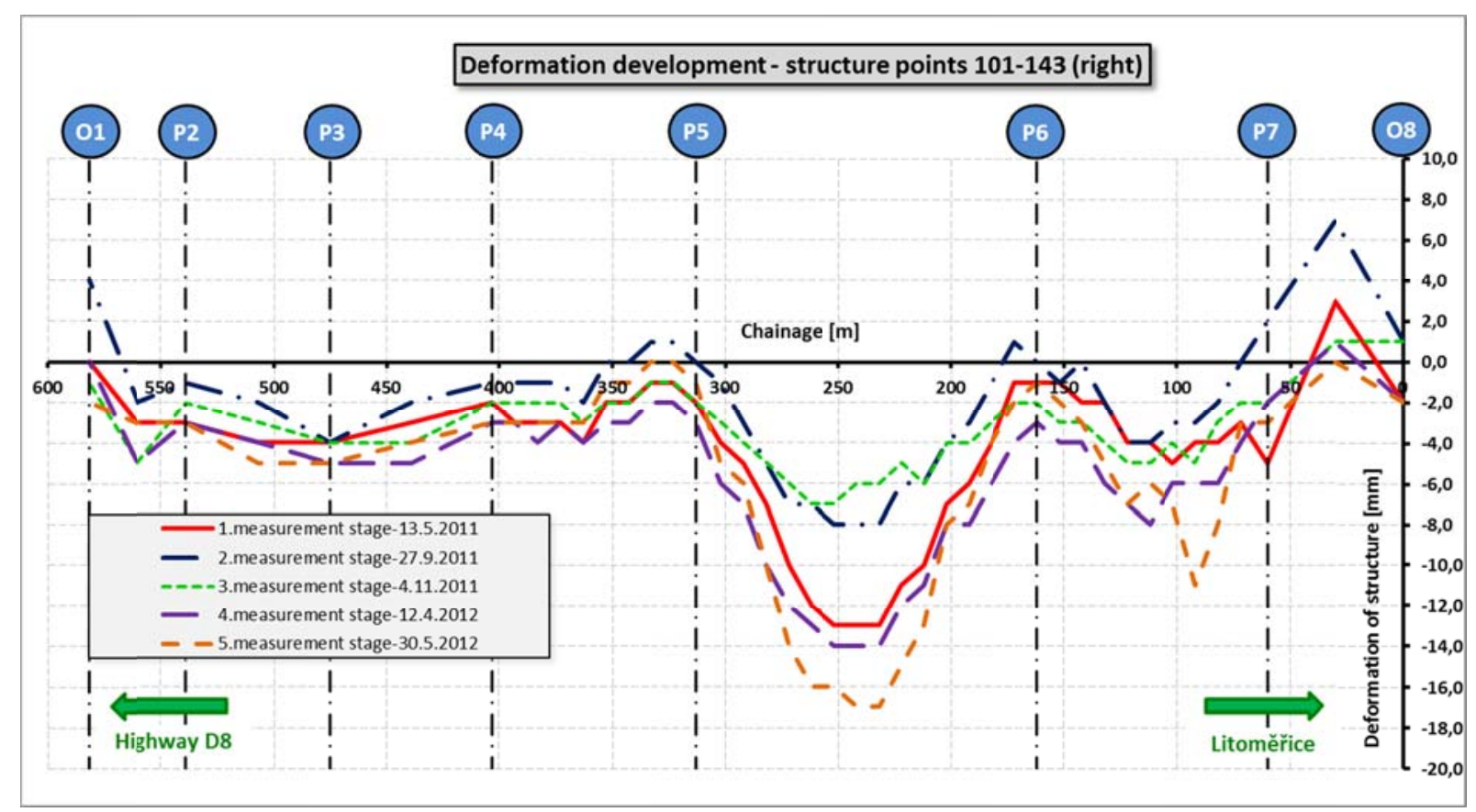

Fig. 8. Development of structure deformation compared $0^{\text {th }}$ measurement stage (right) 


\subsection{Measurement of stages on bridge near Mělník}

Measurements on bridge near Mělník were carried out in dates specified in the Table 2. Temperature ranges are also specified for each stage. Measurements were always successful with results controls confirming the desired accuracy.

Table 2. Measurement stages

\begin{tabular}{|c|c|c|c|}
\hline \multicolumn{4}{|c|}{ Measurement stages } \\
\hline Stage & Date and time & $\begin{array}{c}\text { atmosphere } \\
\text { temperature }\left({ }^{\circ} \mathbf{C}\right)\end{array}$ & $\begin{array}{c}\text { structure } \\
\text { temperature }\left({ }^{\circ} \mathbf{C}\right)\end{array}$ \\
\hline $\mathbf{0 .}$ & $29.3 .2008(22: 30-4: 00,30.3 .2008)$ & $12,5-8,0$ & $13,0-8,0$ \\
\hline $\mathbf{1 .}$ & $1.7 .2008(23: 30-3: 25,2.7 .2008)$ & $22,5-16,5$ & $23,5-18,5$ \\
\hline $\mathbf{2 .}$ & $2.7 .2008(11: 43-16: 21,2.7 .2008)$ & $28,0-31,4$ & $38,3-43,2$ \\
\hline
\end{tabular}

Three measurements were determined by the relative heights of all monitored points from the reference geodetic connection point. Displacements (structure deformation) of 1 st stage to the base 0th stage are shown on Fig. 9. There is a comparison for study of development of construction in the longer term (3 months). On Fig. 10 are compared 2nd and 3rd stages for study of development due to temperature changes. Height of deformation (deviation) in figures was magnified a hundred times. The deformation in the main field is clearly visible.

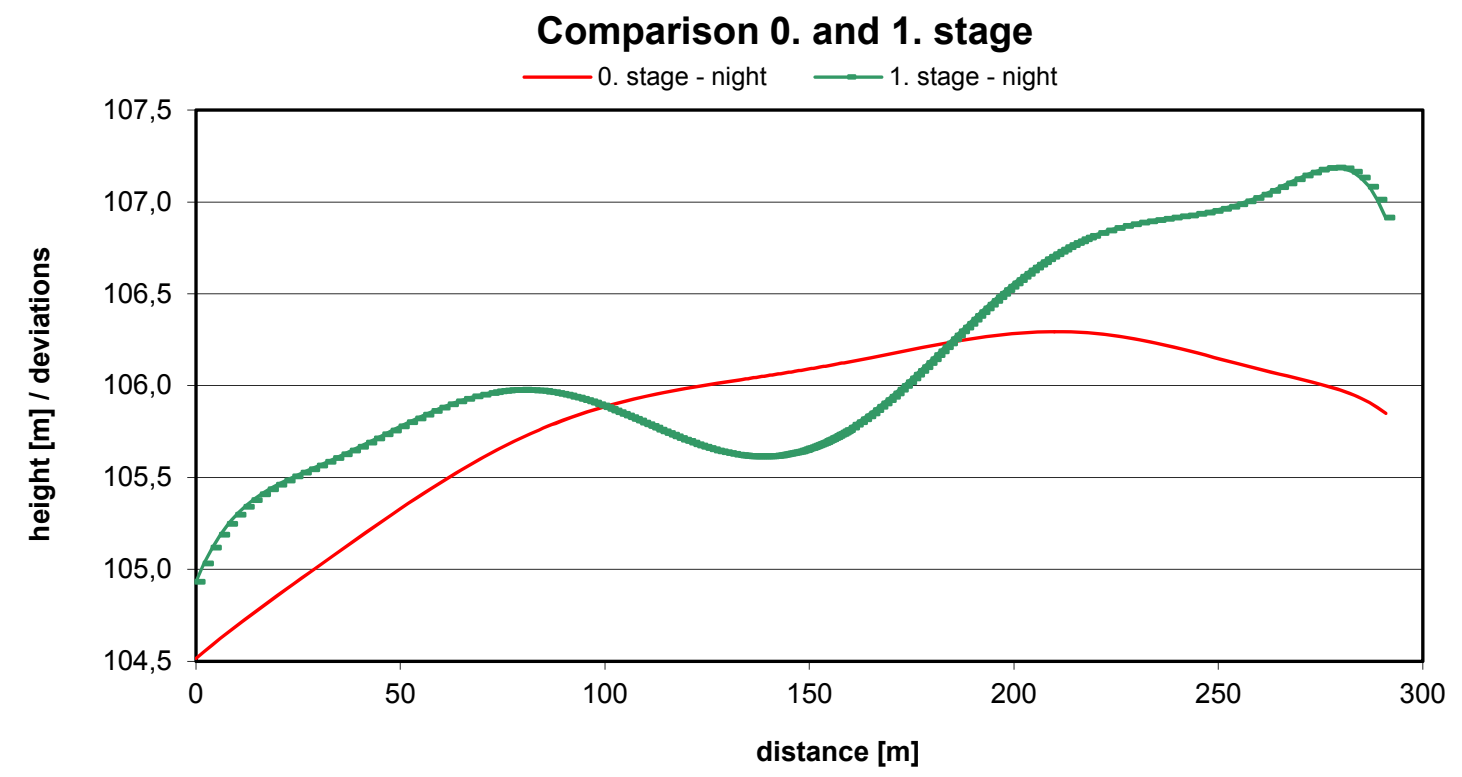

Fig. 9. Comparison $0^{\text {th }}$ and $1^{\text {st }}$ stage (night) 


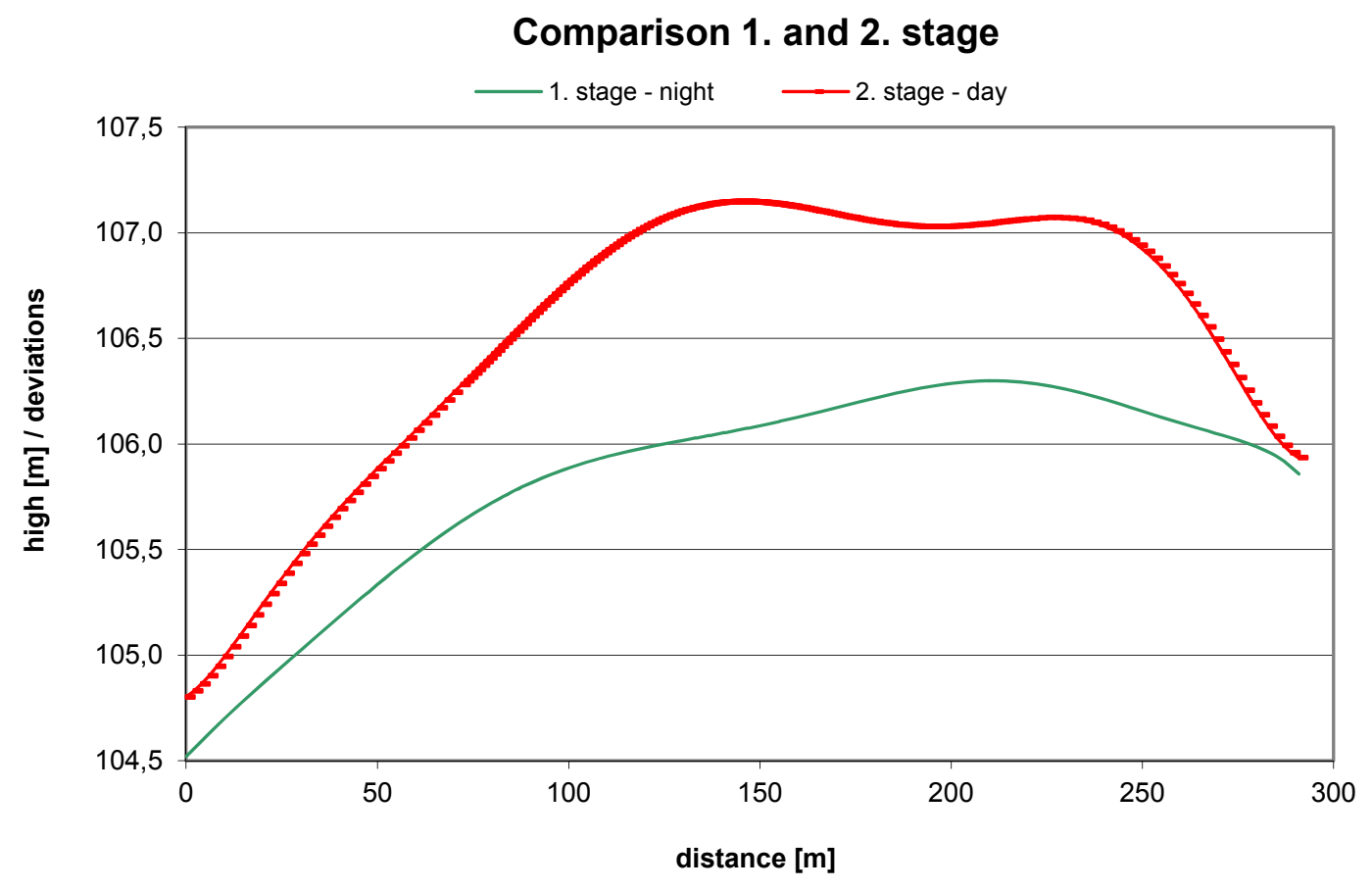

Fig. 10. Comparison $1^{\text {st }}$ and $2^{\text {nd }}$ stage (night - day)

\subsection{Measurement of stages on bridge near Brzotice}

Measurements on bridge near Brzotice were carried out in dates specified in the Table 3. Temperature ranges are also specified for each stage. Measurements were always successful with results controls confirming the desired accuracy.

Table 3. Measurement stages

\begin{tabular}{|c|c|c|c|}
\hline \multicolumn{4}{|c|}{ Measurement stages } \\
\hline Stage & Date and time & $\begin{array}{c}\text { atmosphere } \\
\text { temperature }\left({ }^{\circ} \mathrm{C}\right)\end{array}$ & $\begin{array}{c}\text { structure } \\
\text { temperature }\left({ }^{\circ} \mathrm{C}\right)\end{array}$ \\
\hline $\boldsymbol{0 .}$ & $6.5 .2009(22: 00-23: 30)$ & 9,0 & 8,0 \\
\hline $\mathbf{1 .}$ & $7.5 .2009(11: 00-12: 30)$ & 22,0 & 26,0 \\
\hline
\end{tabular}

Two measurements were determined by the relative heights of all monitored points from the reference geodetic connection point. Displacements (structure deformation) of 1st stage to the base 0th stage are shown on Fig. 11. There is a comparison for study of development due to temperature changes. Height of deformation (deviation) in figure was magnified a hundred times. Two raised significant places in the picture correspond with inner joints of structure. 


\section{Comparison stages night - day}

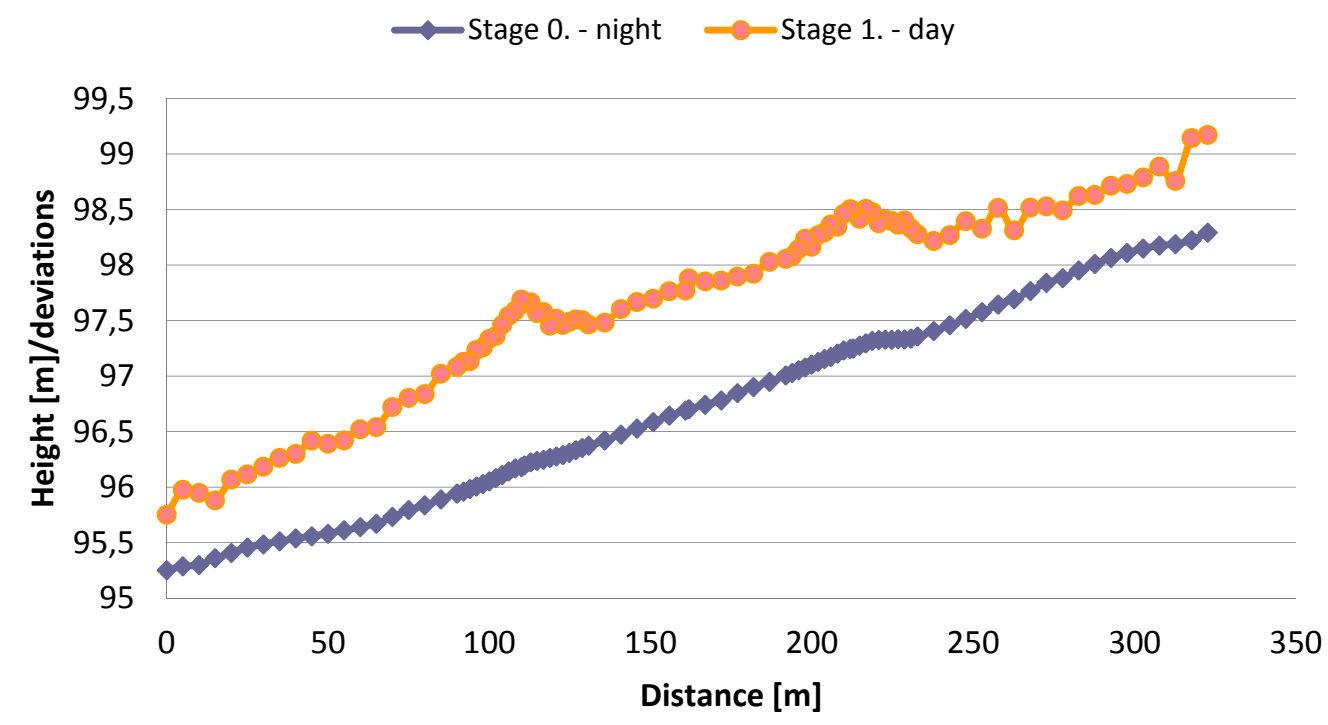

Fig. 11. Comparison $0^{\text {th }}$ and $1^{\text {st }}$ stage (night - day)

\section{Conclusions}

Systematic measurement of deformation of the structure using a relatively large number of monitored points was carried out. The most modern methods of engineering geodesy are used and the time sample method was successfully applied for changes of temperatures on structure. This ensures the greatest accuracy and reliability of the measurements and derived results. So far, this is a very short time interval, in which the development of deformations (deflections) is monitored. It is very early to conclude about the future development trend of structure deflection. However, these results are very important as we get them from the initial development of deformation and it will be possible to accurately calibrate the parallel computing and carried out a sensitivity analysis of the structural behaviour. This systematic measurement will continue with the same intensity and scope. Together with other results from future measurements we obtain a very large file that can be used for better understanding of the complex behaviour of these structures. This is another step towards creating an entirely general methodology for prediction of longterm behaviour of prestressed concrete structures with large spans, which will be used for the safe and reliable design corresponding to the behaviour of real structures.

\section{Acknowledgement}

The article was written with support from the internal grant of CTU in Prague No. SGS13/059/OHK1/1T/11 "Optimization of 3D data acquisition and processing for the needs of engineering geodesy“. 


\section{References}

Křístek, V. \& Vráblík, L. (2007). Optimisation of tendon layout to avoid excessive deflections of long-span prestressed concrete bridges. Concrete Engineering International UK, Volume 11, Number 1

Štroner, M. \& Hampacher, M. (2011). Zpracování a analýza měření v inženýrské geodézii, 1. Vydání Praha, CTU Publishing house

Štroner, M., Urban, R., Vráblík, L.\& Matouš, Z. (2012). Measurement of deflection line on the General Chabera Bridge in Litoměřice. Geodesy, Cartography and Geographic Information Systems 2012 [CD-ROM]. Košice: Berg Faculty TU Košice, pp. 1-10. ISBN 978-80-553-1173-9.

Vráblík, L., Štroner, M. \& Urban, R. (2009). Measurement of bridge body across the river Labe. Acta Montanistica Slovaca. 2009, vol. 14, no. 1, p. 79-85. ISSN 13351788.

Vodsloň, J. Časový vývoj trvalých průhybů velkých mostů z předpjatého betonu; Zprávy o výsledcích dlouhodobých sledování vybraných mostů pozemních komunikací za roky 1995 - 2007

\section{Authors:}

Ing. Rudolf Urban, Ph.D. ${ }^{1)}$, rudolf.urban@fsv.cvut.cz

Doc. Ing. Martin Štroner, Ph.D. ${ }^{1)}$, martin.stroner@fsv.cvut.cz

1) CTU in Prague, Faculty of Civil Engineering, Department of Special Geodesy

Thákurova 7, Prague 6, 16629 Czech Republic 